\title{
Patterns of Information Seeking Among Israeli 12th Grade High School Students Writing Final Research Papers
}

\section{MOSHE YITZHAKI AND MIHAL BIBI}

\author{
Department of Information Studies, \\ Bar-Ilan University, \\ Ramat - Gan, Israel \\ yitzhm@mail.biu.ac.il
}

\begin{abstract}
The purpose of the present study was to examine areas of interest and information seeking patterns of Israeli $12^{\text {th }}$ graders who engaged in research work for their final research paper, an optional partial requirement for obtaining an official matriculation diploma. A detailed questionnaire, based on former studies was disseminated in high schools all over the country, yielding 200 usable questionnaires.
\end{abstract}

Main findings: topping the list of chosen topics were the humanities (44\%), followed by the sciences ( $33 \%$ ), and the social sciences $(24 \%)$. Considerable differences were found between girls and boys. Girls preferred topics from the social sciences (mainly sociology) and from the humanities (except history) while boys preferred scientific topics.

Most respondents had a computer at home (93\%) which was usually connected to the Internet (78\%) and they had taken some computer course in the past $(70 \%)$ although a considerable proportion, more girls than boys, did not make use of them.

Gender was found to be significantly associated with the chosen field. Taking a computer course and use of home Internet were found to be associated with searching the Internet in the process of information seeking while working on the final paper. A home computer connected to the Internet was associated with the use of formal and informal information sources. The school library was the most-visited one followed by academic, public and home libraries. However, a considerable proportion of the respondents reported no or few visits only.

Most respondents reported receiving only little or no advice and guidance regarding the library and database searching. When guidance was provided, it usually consisted of a single-session on a personal basis. Guidance given by a teacher was frequently face to face, with the student more likely to use an OPAC, while when given by a university teacher it was usually in front of a computer, followed by lesser use of OPACs. In summation, although most students were aware of powerful new IT tools, their use is not as prevalent as may be assumed, mainly due to poor or inadequate guidance. 


\section{INTRODUCTION}

Recent developments in information technology, especially in the Internet and the electronic media, have provided scientists and scholars with swifter and more advanced tools for information seeking and transfer. One of the interesting questions in this context is to what extent have these developments affected the information seeking patterns of high school students doing independent research work, culminating in a final paper, as partial fulfillment of their scholastic requirements?

\section{Literature Review}

The vast body of research accumulated in recent years concerning patterns of information seeking and use of high school students doing independent research work, precludes a comprehensive literature review, allowing only a brief and partial one. Mancall \& Drott (1980) were among the first to study library use by high school students doing independent research, while Getz (1985) and Getz \& Shoham (1988) did similar studies in Israel. All three studies concluded that the school library was the most used, both in the US and in Israel. Studying the process of writing final research papers in biology by high school students in Israel, Shtater (1998) found wide dispersion among the students regarding library use, ranging from permanent users to non-users.

Chen (1993) and Nahl \& Harada (1996) studied the search behavior of high school students when using an online catalog. The use of databases on CD-ROM by students at the school library media center was studied by Barlow et al (1987) and by Neuman (1995), while Soloway \& Wallace (1997) and Fidel et al (1999) studied Internet searching by those students. Generally speaking, most studies indicated rather poor mastery of electronic systems, both technically and conceptually.

Getz (1988) Latrobe \& Havener (1997) and Shtater (1998) found that high school students tend to refer to informal sources, i.e. people, like teachers, librarians, parents, rather than to formal bibliographic tools.

Concerning the gender effect, Burdick (1996) found considerable gender differences regarding the topic of search, feelings and attitudes towards their task, and emotional involvement. Boys preferred 'masculine' and 'logical' topics and reported less emotional involvement, while girls preferred 'emotional' topics, reporting a higher emotional involvement. Burdick (1996), in fact, found no significant differences between genders in use patterns of electronic information sources, but Donitza-Schmidt \& Levin (1997) did find that boys had a higher level of computer skills and knowledge and more self-confidence and positive attitudes towards computer, than girls.

The recent shift from survey to case study in investigating the information seeking and use process of high school and undergraduate students in the library, pointed out by Callison (1997) combined with the recent emphasis on information literacy and independent learning and research of school students (AASL \& AECT 1998a, 1998b) has probably promoted the development and formulation of several detailed and elaborate models. Kuhlthau $(1985,1988)$ developed a six-stage model relating to the cognitive and emotional aspects of the information seeking process. Kuhlthau's mental model was further developed by McGregor (1994a, 1994b) who did a qualitative study of cognitive processes involved in Inspiring connections: Learning, libraries \& literacy 
information seeking and use of students, as did Pitts (1995) who distinguished between several interrelating stages in the learning process taking place during information seeking. A former study indicated that past experience with computers has created in users a mental model of the search process which eased a subsequent interaction with electronic databases (Leibscher \& Marchionini, 1988).

\section{BACKGROUND}

The Israeli Ministry of Education allows. high school students to do individual research work, culminating in a final paper, on a chosen topic, as partial fulfillment of their scholastic duties in that subject field. The school principal appoints a certain teacher, holding at least a master's degree, to serve as the school coordinator for handling independent research work and the resultant final papers. This teacher-coordinator is responsible for contacts with the special district supervisor appointed by the Ministry of Education, as well as for locating a personal advisor for each student, signing a formal agreement with them, maintaining contact with them and solving ad-hoc problems. To qualify as a personal advisor, one must either be a faculty member in a higher education institution, a teacher with master's degree or an expert to the subject. Upon completion of the research project and paper, the Ministry of Education pays the advisor a certain relatively low sum (US $\$ 150$ of which $50 \%$ is deducted as income tax), rendering it very difficult to find qualified external experts willing to undertake this task. In fact, many students reported that they had obtained their personal advisor through personal and/or family connections, e.g. friends of parents, relatives etc.

\section{Purpose of the Study and Research Questions}

The present study sought to examine the information seeking patterns among Israeli 12th grade high school students who conducted during the recent months research work for their final research paper, in lieu of the exams required for an official matriculation diploma. More specifically, the research questions were:

1. What are the demographic and educational backgrounds of high school students who opt to write a final research paper rather than take a matriculation exam?

2. What are the information seeking patterns of these students and to what extent do they make use of OPACs, computerized bibliographical databases, and the Internet?

3. To what extent do these students utilize the sophisticated search techniques offered by the abovementioned tools?

4. From whom do such students receive guidance and supervision and to what extent?

5. What relations exist between certain demographic and educational variables and some of the information seeking patterns revealed?

\section{METHODOLOGY}

A lengthy detailed questionnaire was composed, based on former studies done in the US and in Israel, consisting of 43 questions on seven pages. Three groups of questions were 250

Inspiring connections: Learning, libraries \& literacy 
included: demographic and personal details, patterns of information seeking and use, and patterns of instruction in using information sources. The questionnaire was pretested in late December 1999 by being distributed to 30 students, who were eventually included in the final sample. Later, during the first half of 2000, copies of the final version were disseminated among 12th graders in high schools throughout the country; who agreed to participate in the study, yielding additional 170 usable questionnaires and raising the total to 200. Almost all students had conducted bibliographical searches for their final paper, several months earlier (during end of 11 th grade, summer vacation and beginning of 12 th grade) so their answers based on memory were presumed to be reliable enough.

The 200 respondents comprise about $10 \%$ of the approximately 2,000 high school students who wrote such final term papers in Israel last year, out of almost 86,000 12th graders in the country: 72,500 in the Jewish sector and 13,500 in the Arab sector.

The selection of schools for the sample was done in several stages. To qualify for inclusion in the sample, schools had to have a fairly good computerized library collection, computers connected to the Internet and computerized databases accessible to their students and of course, students doing those final term-papers. Schools meeting these conditions were selected from a nation-wide list of over 500 high schools and about forty schools were selected from various parts of the country, using the quota method sampling, in order to ensure maximal sample representativeness. These forty schools were then telephoned by the researchers and asked to permit their students to participate in the study. Unfortunately, though, many schools declined to cooperate for various reasons, mainly lack of time, (and/or unwillingness?!) on the part of teachers. Only 18 schools responded affirmatively and were willing to comply, with opening their doors to an outsider. The researcher then visited the schools and disseminated the questionnaire to those students who had written a final paper in the previous school year. Thirteen of the 18 schools included in the final sample were located in cities or towns and the remaining five existed in small rural settlements (including Kibbutz type) thus covering both urban and rural populations in the north, center and south of the country.

Thus, it is difficult to call the final sample a random one and statistically prove its representativeness since it was limited to consenting schools. However, our intuitive feeling is that while the final sample may not represent the average Israeli high school, it likely reflects the 50 upper centiles, which are well-equipped with regard to library computerization.

The data gathered were statistically analyzed using the SAS@ package, yielding descriptive statistics of the 200 students sampled as well as measures of association and correlation between variables. The quantity of tables and analyses was much beyond the limited space allotted to the current paper and thus only a selection is presented here.

\section{MAIN FINDINGS AND DISCUSSION}

\section{General Background of Respondents}

About two-thirds of the respondents were female (130) while only $35 \%$ (70) were male, with $45 \%$ living in large cities, $28 \%$ in smaller ones and about $23 \%$ coming from rural areas, i.e. small agricultural settlements, including 'Kibbutzim'. 
Concerning the schools' geographical location, about half of the respondents attended schools in the Greater Tel-Aviv area and the central part of the country, close to $40 \%$ studied in the north (Haifa and northward) and the remaining 12\% came from the capital Jerusalem and the south. About half of the respondents admitted knowing little about the topic before beginning their research, 36\% reported 'partial' knowledge and only $17 \%$ reported having extensive knowledge. A considerable percentage (40\%) reported that at least one of their parents dealt with computers, either professionally or as a hobby, and close to two-thirds of both parents had an academic education.

About $70 \%$ had taken some computer course in the past and $93 \%$ (186 respondents) owned a home computer. However, as seen in Table 1, 23.5\% never used it and combined with those without a computer at home (7\%) resulted in 30\% who lacked past computer experience at home. Thirty percent used their home computer up to three hours a week, about $24 \%$ between $4-9$ hours, and only $16 \%$ used it over 9 hours. The mean use for those having a home computer was 3.88 hours per week and 3.61 for the entire sample of 200 (SD = 4.1). The median use for the whole sample, however, was considerably lower, only 1.86 hours, which clearly indicates a very negatively skewed distribution, due to concentration of over $60 \%$ of the cases under the three hours limit.

Table 1

\section{Extent of Computer and Internet Use at Home}

\begin{tabular}{|c|c|c|c|c|}
\hline \multirow[b]{2}{*}{ Weekly Use (in hours) } & \multicolumn{2}{|c|}{ Computer Use at Home } & \multicolumn{2}{|c|}{ Internet Use at Home } \\
\hline & $\underline{\mathrm{n}}$ & $\underline{\%}$ & $\underline{\mathrm{n}}$ & $\underline{\%}$ \\
\hline $\begin{array}{l}\text { No computer (or Internet) } \\
\text { at Home }\end{array}$ & 14 & 7 & 44 & 22 \\
\hline No Use at all & 47 & 23.5 & 41 & 20.5 \\
\hline Less than 1 hour & 28 & 14 & 30 & 15 \\
\hline $1-3$ & 32 & 16 & 36 & 18 \\
\hline $4-6$ & 28 & 14 & 24 & 12 \\
\hline $7-9$ & 19 & 9.5 & 6 & 3 \\
\hline $10-12$ & 32 & 16 & 19 & 9.5 \\
\hline Total & 200 & $100 \%$ & 200 & $100 \%$ \\
\hline
\end{tabular}

Close to $80 \%$ (156 respondents) were connected to the Internet at home, but $20.5 \%$ never used it, meaning that only 115 of the sample (57.5\%) made any use of the Internet at home (Table 1). Another 33\% surfed up to three hours a week, $15 \%$ between $4-9$ hours and only less than $10 \%$ over 9 hours. The mean use for those with home computers connected to the Internet was 2.97 hours per week and 2.32 for the entire sample of 200 . Evidently, Internet use at home was significantly lower than that of computer use at home $(p<0.01)$. Here again, the median use for the whole sample, however, was considerably lower, only 
0.50 hours, which clearly indicates here too a very negatively skewed distribution, due to concentration of over $57 \%$ of the cases under the one hour limit.

\section{Area of Topic Chosen}

About $44 \%$ of the whole sample of 200 respondents chose their topic from one of the humanities fields, mostly history, $33 \%$ from the sciences and the rest $(24 \%)$ from the social sciences fields, mainly sociology.

From those choosing a humanities topic, about two-thirds preferred history, usually Jewish history, with a strong preference for the Holocaust period. In the sciences, the favorite topic was biology $(46 \%)$ followed by agriculture, physics and technology, but with much lower rates of about $12 \%$ each. In the social sciences, the vast majority (77\%) chose a sociology topic, with psychology far behind chosen by merely $17 \%$.

Gender was found to be significantly associated with the chosen field: while more than half $(53 \%)$ of the male students chose a scientific topic, only $22 \%$ of the females did so. The opposite was true for the social sciences, chosen by $32 \%$ of the females vs. only $10 \%$ of the males. A humanities topic was chosen by $47 \%$ of the females, and $37 \%$ of the males.

\section{Table 2}

Relation between Gender and Broad Area of Knowledge of Chosen Topic

\begin{tabular}{|c|c|c|c|c|c|c|c|}
\hline \multirow[t]{2}{*}{ Gender } & \multicolumn{2}{|c|}{ Humanities } & \multicolumn{2}{|c|}{ Soc. Sciences } & \multicolumn{2}{|c|}{$\underline{\text { Sciences }}$} & Total \\
\hline & $\underline{\%}$ & (n) & $\%$ & (n) & $\%$ & (n) & $\underline{N}$ \\
\hline Girls & 70.1 & $(61)$ & 85.4 & $(41)$ & 43.1 & (28) & $65 \quad(130)$ \\
\hline Boys & 29.9 & (26) & 14.6 & (7) & 56.9 & (37) & (70) \\
\hline Total & $100 \%$ & $(87)$ & $100 \%$ & $(48)$ & $100 \%$ & $(65)$ & $100 \%(200)$ \\
\hline$X^{2}=23.5$ & \multicolumn{4}{|c|}{$P<0.01$} & \multicolumn{3}{|c|}{$\mathrm{C}$ coefficient $=0.32$} \\
\hline
\end{tabular}

The same gender difference regarding the broad area of chosen topic can be analyzed from another perspective as shown in Table 2: girls who accounted for $65 \%$ of the total sample, comprised $70 \%$ of the students choosing a humanities topic and $85 \%$ of those choosing a social sciences topic, but only $43 \%$ of those chose a topic from the sciences, considerably less than their share in the sample. On the other hand, boys $(35 \%$ of the sample) comprised only $30 \%$ of the humanities topics, less than $15 \%$ of the social sciences topics, but $57 \%$ of the scientific topics, 1.6 times more than their share in the sample. Chisquare analysis for association between the two variables $\left(\mathrm{X}^{2}=23.5\right)$ was found highly significant at $\mathrm{P}<0.01(\mathrm{C}$ coefficient $=0.32)$. 
Table 3

Relation between Gender and Field of Chosen Topic

\begin{tabular}{|c|c|c|c|c|}
\hline $\begin{array}{l}\text { Subject Field of Chosen } \\
\text { Topic }\end{array}$ & $\frac{\text { Females }}{\underline{\%}}$ & $\frac{\text { Males }}{\underline{\%}}$ & $\frac{\text { Total }}{\underline{N}}$ & $\frac{\text { Total }}{\%}$ \\
\hline History & 26.9 & 34.3 & 59 & 29.5 \\
\hline Other Humanities & 20.0 & 2.9 & 28 & 14.0 \\
\hline Sociology & 24.6 & 7.1 & 37 & 18.5 \\
\hline Other Social Sciences & 7.0 & 2.8 & 11 & 5.5 \\
\hline $\begin{array}{l}\text { Technology, Physics and } \\
\text { Computers }\end{array}$ & 1.5 & 22.9 & 18 & 9.0 \\
\hline Biology and Agriculture & 17.7 & 21.4 & 38 & 19.0 \\
\hline Other Sciences & 2.3 & 8.6 & 9 & 4.5 \\
\hline Total & $100 \%$ & $100 \%$ & & \\
\hline $\mathrm{N}$ & 130 & 70 & 200 & $100 \%$ \\
\hline
\end{tabular}

From the more detailed breakdown given in Table 3 the following conclusions may be drawn, based on statistically significant differences $(p<0.01)$ :

- While historical topics were chosen by relatively more boys $(34.3 \%$ of the boys vs. $27 \%$ of the girls) a huge opposite difference was found regarding other humanities fields (e.g. literature, biblical studies, philosophy, fine arts and musicology) which were chosen by $20 \%$ of the girls vs. only $3 \%$ of the boys!

- Interestingly, the proportion of girls who chose a sociology topic was three times higher than boys $(24.6 \%$ vs. $7.1 \%)$ and the same was true for other social sciences fields chosen, mainly psychology.

- Concerning the sciences, in technology, physics and computer science, the proportion of boys was tremendously higher ( $23 \%$ vs. only $1.5 \%$ among the girls). Excluding biology, for which girls displayed a slight relative preference (16\% vs. $13 \%$ ), in the remaining fields, mainly agriculture ( $8.6 \%$ vs. $1.5 \%$ ) again there was a much higher preference among boys.

\section{The Information Seeking Process}

Computer and Internet Experience and Gender. Table 4 indicates that past computer experience at home apparently affects certain patterns of the information seeking process, since a significant association was found between the extent of computer use at home and searches on a computerized database. The mean number of weekly hours of computer use at home of those students who did search an electronic database during their work on the final paper was significantly higher than the mean of the group who did not do such a search (4.06 vs. 2.78). 


\section{Table 4}

Relation Between Extent of Computer Use at Home and Searches on a Computerized Database in Information Seeking Process During Work on Final Paper

\begin{tabular}{cc}
\hline $\begin{array}{c}\text { Hours Per Week of } \\
\text { Computer Use at Home } \\
\text { (Mean and SD) }\end{array}$ & $\begin{array}{c}\text { Searches on a Computerized } \\
\text { Database during } \\
\text { Work on Paper }\end{array}$ \\
\hline $4.06(3.79)$ & Yes \\
$2.78(3.45)$ & No \\
$\mathrm{N}$ & 186 \\
Not Applicable * & 14 \\
Total Sample & 200 \\
$\mathrm{t}$ & 1.95 \\
$\mathrm{P}<$ & 0.05 \\
\hline
\end{tabular}

* No computer at home

Table 5 indicates that past Internet experience at home apparently affects certain patterns of the information seeking process, since a significant association was found between the extent of computer use at home and searches on the Internet while seeking information for the final paper. Again, the mean number of weekly hours of computer use at home of those students who did search the Internet during their work on the final paper was significantly higher than the mean of the group who did not do such a search (5.10 vs. 2.04).

\section{Table 5}

Relation Between Extent of Computer Use at Home and Searches on the Internet in the Process of Information Seeking During Work on Final Paper

\begin{tabular}{cc}
$\begin{array}{c}\text { Hours Per Week of Computer Use at } \\
\text { Home (Mean and SD) }\end{array}$ & $\begin{array}{c}\text { Searches on Internet during } \\
\text { Work on Final Paper }\end{array}$ \\
\hline $5.10(3.71)$ & Yes \\
$2.04(3.10)$ & No \\
$\mathrm{N}$ & 143 \\
Not Applicable * & 57 \\
Total Sample & 200 \\
$\mathrm{t}$ & 4.95 \\
$\mathrm{P}<$ & 0.01 \\
\hline
\end{tabular}

* No computer (14) or Internet (30) at home and missing data (13) 
Table 6 indicates a statistically significant, though not strong, correlation (at $\mathrm{P}<$ 0.05 ) between having attended a computer course in the past and having a home computer connected to the Internet on one hand and searching the Internet while seeking information for the final paper, on the other hand.

\section{Table 6}

Relation Between Computer Knowledge and Internet Connection at Home and Searches on the Internet while Seeking Information for the Final Paper

\begin{tabular}{|c|c|c|c|c|}
\hline \multirow{3}{*}{$\begin{array}{l}\text { Searching the Internet } \\
\text { in Doing Final Paper }\end{array}$} & \multicolumn{2}{|c|}{$\begin{array}{c}\text { Attended a Computer } \\
\text { Course } \\
\text { in the Past } \\
\end{array}$} & \multicolumn{2}{|c|}{$\begin{array}{c}\text { Home Computer } \\
\text { Connected to the } \\
\text { Internet }\end{array}$} \\
\hline & Yes & No & Yes & \multirow{2}{*}{$\begin{array}{l}\text { No } \\
\% \quad \underline{(n)}\end{array}$} \\
\hline & $\% \quad$ (n) & $\% \quad$ (n) & $\% \quad$ (n) & \\
\hline Yes & $69.4(75)$ & $50(22)$ & $68.9(89)$ & $43.8(7)$ \\
\hline No & 30.6 & $50(22)$ & $31.1(40)$ & $56.2(9)$ \\
\hline Total & $\begin{array}{l}100 \% \\
(108)\end{array}$ & $\begin{array}{c}100 \% \\
(44)\end{array}$ & $\begin{array}{l}100 \% \\
(129)\end{array}$ & $\begin{array}{l}100 \% \\
(16)\end{array}$ \\
\hline Total N & \multicolumn{2}{|c|}{152} & \multicolumn{2}{|c|}{145} \\
\hline $\mathrm{X}^{2}$ & \multicolumn{2}{|c|}{5.12} & \multicolumn{2}{|c|}{4.1} \\
\hline$P$ & \multicolumn{2}{|c|}{$<0.05$} & \multicolumn{2}{|c|}{$<0.05$} \\
\hline phi coefficient & \multicolumn{2}{|c|}{0.18} & \multicolumn{2}{|c|}{0.17} \\
\hline $\mathrm{C}$ coefficient & \multicolumn{2}{|c|}{0.18} & \multicolumn{2}{|c|}{0.17} \\
\hline
\end{tabular}

Aimost $70 \%$ of the students who had taken a computer course reported searching the Internet when working on their final project, while of those who had not previously taken a computer course only 50\% conducted Internet searches. Similarly, close to $70 \%$ of the students whose home computer was connected to the Internet had searched the Internet when working on their final project, but only $44 \%$ of their 'unconnected' peers had done so.

Strong associations were found between gender and average extent of computer and Internet use at home. The mean number of hours of computer use among boys was more than double that of girls (5.62 vs. 2.70 ) and Internet use was almost two-fold (4.14 vs. 2.16 ). There was, however, greater variability among the girls, as indicated by the SD.

This considerable difference between boys and girls concerning computer and Internet use at home, combined with the abovementioned findings (Tables 4 to 7 ) of significant association between past use of computer and Internet at home on one hand and 
extent of electronic searches during work on final paper on the other hand, naturally lead to the hypothesis that boys would probably do more Internet search compared to girls, during their work on the final paper. This hypothesis, in fact, was confirmed by the figures presented in Table 7.

\section{Table 7}

Relation Between Gender of Student and Internet Search During Work on Final Paper

\begin{tabular}{|c|c|c|c|c|c|c|}
\hline \multirow{2}{*}{$\begin{array}{l}\text { Internet Search during } \\
\text { Work on Paper }\end{array}$} & \multicolumn{2}{|c|}{ Girls } & \multicolumn{2}{|c|}{ Boys } & \multicolumn{2}{|c|}{ Total } \\
\hline & & (n) & $\%$ & (n) & $\%$ & (n) \\
\hline Yes & 54.1 & (53) & 81.5 & (44) & 63.8 & (97) \\
\hline No & 45.9 & (45) & 18.5 & (10) & 36.2 & (55) \\
\hline Total & $100 \%$ & (98) & $100 \%$ & (54) & $100 \%$ & (152) \\
\hline
\end{tabular}

As shown in Table 7, significant gender differences in Internet use also emerged in the process of seeking information for the final paper. Of the 54 boys who reported using some type of an electronic information source during information seeking, over $80 \%$ used the Internet vs. only $54 \%$ of the girls. Chi-square analysis for association between the two variables was highly significant at $\mathrm{P}<0.01$ (phi and $\mathrm{c}$ coefficients $=0.23$ ).

\section{Use of formal and informal information sources}

In collecting the research material, the majority (56\%) were primarily assisted by informal sources, i.e. teacher, librarian, supervisor etc. Only $15 \%$ relied mainly on formal sources, like catalogs, bibliographical databases, etc., and about $30 \%$ were equally assisted by both types of sources.

Table 8

Relation Between Owning a Home Computer Connected to the Internet and Type of Information Sources Referred to

\begin{tabular}{|c|c|c|c|c|c|c|}
\hline \multicolumn{7}{|c|}{ Home Computer Connected to the Internet } \\
\hline \multirow{2}{*}{$\begin{array}{l}\text { Information Sources } \\
\text { Referred to }\end{array}$} & \multicolumn{2}{|c|}{ Yes } & \multicolumn{2}{|c|}{ No } & \multicolumn{2}{|c|}{ Total } \\
\hline & $\underline{\mathrm{n}}$ & \% & $\underline{\mathrm{n}}$ & \% & $\underline{\mathrm{n}}$ & $\underline{\%}$ \\
\hline Formal & 74 & 47.4 & 8 & 26.7 & 82 & 44.1 \\
\hline Informal & 82 & 52.6 & 22 & 73.3 & 104 & 55.9 \\
\hline Total & 156 & $100 \%$ & 30 & $100 \%$ & 186 & $100 \%$ \\
\hline \multicolumn{3}{|c|}{$\begin{aligned} X^{2} & =12.62 \\
P & <0.01\end{aligned}$} & \multicolumn{4}{|c|}{$\begin{array}{c}\text { phi coefficient. }=0.26 \\
C \text { coefficient }=0.25\end{array}$} \\
\hline
\end{tabular}


Table 8 clearly indicates a statistically significant relation between the two variables: having a home computer connected to the Internet and type of information sources referred to during the process of information seeking. Students whose home computer was connected to the Internet referred almost equally to formal and informal information sources $(47.4 \% \mathrm{vs}$. $52.6 \%$ ) while 'unconnected' ones tended to refer much more to informal information sources (73\%) as compared to formal ones $(27 \%)$. One possible explanation is that the needed information and formal sources were less accessible to 'unconnected' students, obliging them to rely more heavily on informal sources like people who serve as information agents, known as 'gatekeepers'.

\section{Table 9}

\section{Extent of Use of Various Libraries During Work on Final Paper}

\begin{tabular}{cccccc}
$\begin{array}{c}\text { No. of } \\
\text { Visits }\end{array}$ & $\begin{array}{c}\text { Home } \\
\text { Library }\end{array}$ & $\begin{array}{c}\text { School } \\
\text { Library }\end{array}$ & $\begin{array}{c}\text { Public } \\
\text { Library }\end{array}$ & $\begin{array}{c}\text { University } \\
\text { Library }\end{array}$ & $\begin{array}{c}\text { Special } \\
\text { Library }\end{array}$ \\
\hline 0 & 53 & 23.5 & 40 & 38 & 73 \\
$1-5$ & 38 & 50 & 37 & 39 & 18.5 \\
$6-10$ & 5 & 7.5 & 13 & 10 & 5 \\
11 or More & 4 & 19 & 10 & 13 & 3.5 \\
\hline Total & $100 \%$ & $100 \%$ & $100 \%$ & $100 \%$ & $100 \%$ \\
$\mathrm{~N}$ & 200 & 200 & 200 & 200 & 200 \\
\hline
\end{tabular}

Table 9 indicates that the most-used was the school library, visited at least once by $76.5 \%$ of the respondents, followed by the university library $(62 \%)$, public library $(60 \%)$ and home library $(47 \%)$. Special libraries were visited by only a small minority of $27 \%$. Analysis of the heavy use figures (6 visits or more) reveals a similar ranking: the school library with $27 \%$, followed by the university library and the public library $(23 \%$ each) leaving the home library and special library far behind, with only about $9 \%$ each. On the average, the school library received the highest mean number of visits per student (4.6) followed by the university library (3.7) the public library (3.5) the home library (2.1) and the special library (1.4). In all cases the standard deviation was higher than the mean, yielding variability coefficients greater than $100 \%$, indicating a relatively large variability of responses concerning each type of library. Former studies, like those by Drott \& Mancall (1980) and Getz (1985) also found that the school library was the most-used library among high school students.

It should be noted, however, that even the three heavily-used libraries mentioned above were not used at all by $24 \%$ to $40 \%$ of the respondents and were consulted only 1 to 5 times by a considerable proportion of $37 \%$ to $50 \%$ of them. 


\section{Guidance and Supervision of Research Work}

About half the respondents (49\%) reported that their official advisor for writing the final paper was a university faculty member or other research expert, $40.5 \%$ said it was a high school teacher working in their school or other and the rest $(10.5 \%)$ reported the official advisor was another kind of expert not affiliated with one of the abovementioned institutions.

Students were asked to rate on a Likert-type scale the extent of guidance they had received regarding the library, its materials and how to search computerized information sources. The grades ranged from 1 - none, 2 - slight, 3 - considerable, 4 - intensive.

The vast majority (71\%) of the 200 respondents reported receiving fairly poor guidance : almost half (97 or $48.5 \%$ ) reported receiving no guidance at all and $22 \%$ described it as 'slight'. Only less than $30 \%$ described the guidance they received as 'considerable' or 'intensive'. All in all, only 103 students ( $51.5 \%$ of the entire sample) reported receiving at least some practical guidance concerning the library, the materials it contains and how to search computerized information sources.

These figures indicate an inadequate mental model of most respondents regarding their working environment, since they probably lack essential knowledge concerning interaction with all kinds of available information sources, printed as well as computerized, and how to use them effectively and efficiently.

\section{Table 10}

\section{Guidance and Supervision}

\begin{tabular}{ccc}
\hline Advisor for Final Paper & Mean Index Grade & $\underline{\text { SD }}$ \\
\hline Teacher & 1.72 & 1.04 \\
University or Research & 2.07 & 1.08 \\
Expert etc. & & \\
$\mathrm{N}=198$ & $\mathrm{t}=2.25$ & $\mathrm{P}<0.01$ \\
\hline
\end{tabular}

Crossing the mean grades given by students with the type of advisor yielded the figures in Table 10. Those guided by a teacher in their school or another rated the extent of guidance they had received as 1.72 , i.e. even lower than 'slight', while students guided by a university or research person or some other expert rated this guidance considerably higher, at 2.07 , i.e. more than 'slight', the difference being statistically significant at $\mathrm{P}<0.01$. The explanation to this finding may be that university and research people and other subject experts are more familiar with research and professional literature compared to the average high school teacher and are thus more capable than teachers of providing students with intensive guidance on relevant information sources. 
Over half $(51.5 \%)$ of the 103 respondents who did receive at least some guidance, albeit minimal, regarding the library, the materials it contains and the manner of searching computerized information sources, did so from their personal supervisor, about $20 \%$ received it from a librarian, $11 \%$ from a teacher, $7 \%$ from a parent and the remaining $12 \%$ from another unspecified source.

For most $(75 \%)$ of the 103 students receiving such guidance, it was on a personal basis, but usually (61\%) limited to a single session, taking place at the school or university library $(48 \%)$ or at the advisor's home $(23 \%)$.

\section{Table 11}

Frequency, Forum and Type of Practical Guidance Received by the 103 Students Reporting Some Kind of Guidance

\begin{tabular}{cccccc}
\hline$\underline{\text { Frequency }}$ & $\underline{\%}$ & Forum & $\underline{\%}$ & $\underline{\text { Type }}$ & $\underline{\%}$ \\
\hline Single Session & 61.2 & Personal & 74.8 & Frontal & 52.4 \\
Several Sessions & 38.8 & Group & 25.2 & In Front of Computer & 47.6 \\
\hline Total & $100 \%$ & & $100 \%$ & & $100 \%$ \\
N & 103 & & 103 & & 103 \\
\hline
\end{tabular}

Of those 103 students receiving such guidance, over half $(52.4 \%)$ received it face-toface, while $47.6 \%$ (who comprise less than $25 \%$ of the whole sample!) received it in front of a computer. Moreover, of those 49 students almost $60 \%$ reported that they had obtained none, little or partial practice while being guided in front of the computer. Only 21 students, about $10 \%$ of the total sample, reported getting 'much' or 'very much' practice in conducting computerized information searches.

Liebscher and Marchionini (1988) have noted that extended and well-built mental models of the searching environment develop best by active deeds rather than passive theoretical learning. Practical training, which contributes to the cognitive development of the student, clearly has a positive impact on the performance level of the information search, the most important factors being the duration and quality of training. Ongoing exposure to a computerized search environment is likely to improve and extend the mental search model of students.

In view of this, it is apparent that even those students who were guided in front of computers did not receive sufficient practice, not to mention those whose only guidance was face-to-face. 
Table 12

Relation Between Type of Advisor and Form of Guidance

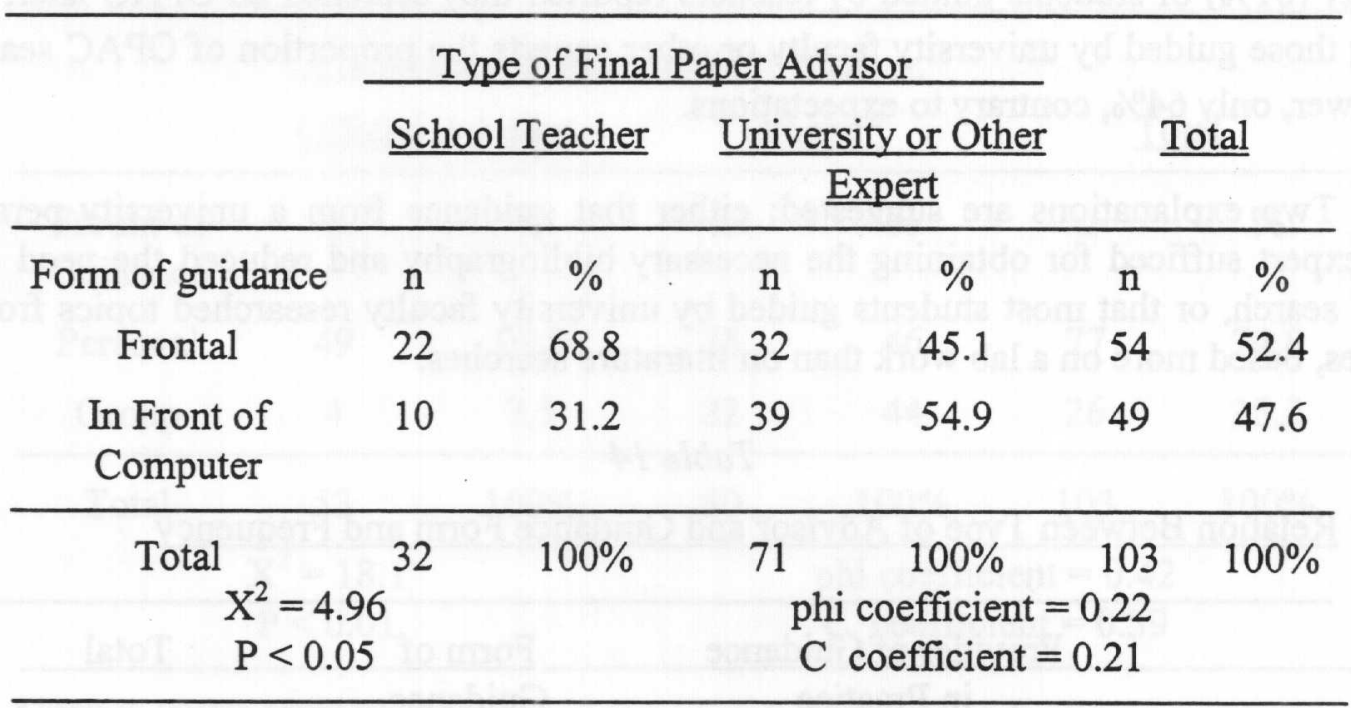

Table 12 indicates a significant, though partial, correlation between type of advisor and form of guidance. In most cases ( $69 \%$ ) guidance by teachers took the form of a face-toface lecture, but when given by university faculty or other expert it was conducted in front of a computer in over half $(55 \%)$ of all cases. It is difficult to determine if this was because computers are more available and accessible to university staff and other experts than to high school teachers or is related to the fact that teachers felt less comfortable in a computer environment or a combination of both. This question requires further study, but the fact remains that more than half of the respondents received their guidance from a face-to-face lecture, a form which seems inadequate in view of the current state of information technology.

Table 13

\section{Relation Between Type of Advisor and OPAC Searches}

\begin{tabular}{|c|c|c|c|c|c|c|}
\hline & \multicolumn{4}{|c|}{ Type of Final Paper Advisor } & \multirow{2}{*}{\multicolumn{2}{|c|}{ Total }} \\
\hline & \multicolumn{2}{|c|}{$\underline{\text { School Teacher }}$} & \multicolumn{2}{|c|}{$\frac{\text { University or Other }}{\text { Expert }}$} & & \\
\hline OPAC Searches & $\mathrm{N}$ & $\%$ & $\mathrm{n}$ & $\%$ & $\mathrm{~N}$ & $\%$ \\
\hline Yes & 50 & 80.7 & 58 & 64.4 & 108 & 71.1 \\
\hline No & 12 & 19.3 & 32 & 35.6 & 44 & 28.9 \\
\hline Total & 62 & $100 \%$ & 90 & $100 \%$ & 152 & $100 \%$ \\
\hline \multicolumn{3}{|c|}{$\begin{aligned} X^{2} & =4.685 \\
P & <0.05\end{aligned}$} & \multicolumn{4}{|c|}{$\begin{array}{c}\text { phi coefficient }=0.18 \\
C \text { coefficient }=0.17\end{array}$} \\
\hline
\end{tabular}


Table 13 indicates a significant, though partial, association between type of advisor and searching an OPAC while seeking information for a final paper. Relatively, the vast majority ( $81 \%$ ) of students guided by teachers reported they searched an OPAC later, while among those guided by university faculty or other experts the proportion of OPAC searchers was lower, only $64 \%$, contrary to expectations.

Two explanations are suggested: either that guidance from a university person or other expert sufficed for obtaining the necessary bibliography and reduced the need for an OPAC search, or that most students guided by university faculty researched topics from the sciences, based more on a lab work than on literature searches.

Table 14

Relation Between Type of Advisor and Guidance Form and Frequency

\begin{tabular}{|c|c|c|c|c|c|c|}
\hline \multirow[b]{2}{*}{$\begin{array}{l}\text { Frequency } \\
\text { of Guidance }\end{array}$} & \multicolumn{2}{|c|}{$\frac{\text { Provider of Guidance }}{\text { in Practice }}$} & \multicolumn{2}{|c|}{$\begin{array}{l}\text { Form of } \\
\text { Guidance }\end{array}$} & \multicolumn{2}{|c|}{ Total } \\
\hline & $\begin{array}{l}\text { Official } \\
\text { Advisor }\end{array}$ & Others * & Frontal & $\begin{array}{l}\text { In Front of } \\
\text { Computer }\end{array}$ & $\mathrm{N}$ & $\%$ \\
\hline $\begin{array}{l}\text { Single } \\
\text { Session }\end{array}$ & 47.2 & 76.0 & 48.2 & 75.5 & 63 & 61.2 \\
\hline $\begin{array}{l}\text { Several } \\
\text { Sessions }\end{array}$ & 52.8 & 24.0 & 51.8 & 24.5 & 40 & 38.8 \\
\hline $\begin{array}{c}\text { Total } \\
\mathrm{N}\end{array}$ & $\begin{array}{c}100 \% \\
53 \\
\mathrm{X}^{2}=4.685 \\
\mathrm{P}<0.05\end{array}$ & $\begin{array}{c}100 \% \\
50\end{array}$ & $\begin{array}{c}100 \% \\
63\end{array}$ & $\begin{array}{c}100 \% \\
40 \\
\text { i coefficient } \\
\text { coefficient }=\end{array}$ & $\begin{array}{l}103 \\
0.18 \\
0.17\end{array}$ & $100 \%$ \\
\hline
\end{tabular}

* librarian, teacher, parent etc.

Table 14 displays the associations found between frequency of guidance actually given to students (by the official advisor or others) on one hand and its form and provider on the other hand. Evidently, when practical guidance was provided by the official advisor, more than half reported that it consisted of several sessions, but when provided by others (librarian, teacher, parent etc.) it usually lasted (76\%) a single session, which is usually considered less effective and useful. In other words, a series of guidance sessions was more likely when practical guidance was provided by the official advisor, which is probably as should be.

Crossing the frequency of guidance and its form reveals that most guidance in front of a computer was limited to a single session, while more than half of the frontal guidance consisted of several sessions. This finding may partially stem from lack of time or inavailability or inaccessibility of computer equipment which limited the frequency of guidance in front of a computer. 
Table 15

Relation Between Provider and Forum of Practical Guidance

\begin{tabular}{|c|c|c|c|c|c|c|}
\hline & \multicolumn{4}{|c|}{ Provider of Practical Guidance } & & \\
\hline & \multicolumn{2}{|c|}{$\underline{\text { Official Advisor }}$} & \multicolumn{2}{|c|}{ Others * } & \multicolumn{2}{|c|}{$\underline{\text { Total }}$} \\
\hline $\begin{array}{l}\text { Forum of } \\
\text { Guidance }\end{array}$ & $\mathrm{n}$ & $\%$ & $\mathrm{n}$ & $\%$ & $\mathrm{n}$ & $\%$ \\
\hline Personal & 49 & 92.5 & 28 & 46 & 77 & 74.8 \\
\hline Group & 4 & 7.5 & 22 & 44 & 26 & 25.2 \\
\hline Total & 53 & $100 \%$ & 50 & $100 \%$ & 103 & $100 \%$ \\
\hline & $\begin{array}{l}X^{2}=18 \\
P<0.0\end{array}$ & & & $\begin{array}{l}\text { hi coeff } \\
\text { C coeffi }\end{array}$ & $\begin{array}{l}t=0 \\
t=0\end{array}$ & \\
\hline
\end{tabular}

* librarian, teacher, parent etc.

Table 15 indicates a fairly strong statistically significant relation between the actual provider of guidance and the forum in which it was given. When provided by the official advisor, in over $90 \%$ of the cases it was done on a one-to-one personal basis. However, when provided by others it was given on a group basis in almost half the cases, probably when given by the librarians or by teachers being solicited to do so by the coordinating teacher responsible for the subject of final papers at that school. This finding reemphasizes the advantages of receiving practical guidance from the official advisor rather than others, although admittedly this may actually not be so simple, as indicated by the low proportion $(26.5 \%)$ of students who actually received the practical guidance from their official advisor. Further inquiry is recommended to find out the reasons for that low proportion.

\section{CONCLUSIONS}

1. Although it is difficult to statistically confirm the representativeness of the sample, due to limited co-operativeness of some of the schools, its wide scope and geographical dispersion merit the assumption that it reflects the target population and that its findings approximately portray the real situation in most Israeli high schools which allow their students to write a final research paper instead of an official matriculation exam.

2. Classifying the topics chosen by the students, according to the broad area of knowledge to which they belong, the humanities top the list $(44 \%)$ followed by the sciences $(33 \%)$ and the social sciences (24\%). Considerable differences were found, however, between girls and boys choices i.e., girls preferred topics from the social sciences (mainly sociology) and from the humanities (except history) while boys preferred scientific topics.

3. Most respondents owned a home computer home (93\%) which was usually connected to the Internet (78\%) and they had attended some computer class in the past (70\%) although a considerable proportion, more girls than boys, did not make use of them. 
4. Gender, having taken a computer course in the past and use of home Internet were found to be associated with searching the Internet while seeking information for the final paper.

5. Connection of one's home computer to the Internet was associated with the use of formal and informal information sources: 'unconnected' students preferred informal sources, i.e. people, like teachers, librarians, advisers etc.

6. The most-visited libraries were: the school library, the academic library, the public library and the home library. However, a considerable proportion of the respondents $(24 \%-40 \%)$ never visited the three first libraries and a higher percentage visited them only one to five times.

7. Most respondents reported receiving only little or no advice and guidance regarding the library, its content and how to search computerized databases. University advisers received higher scores than teachers. When guidance was provided, it was confined to a single-session on a personal basis. When given by a teacher it was frequently face-to-face with the student relying more heavily on OPACs, however when given by a university teacher it was usually in front of a computer, accompanied by a lower use of OPACs.

8. When the guidance was provided by someone other than the official adviser it was usually limited to a single session, while when given by the official adviser it was often on a personal basis and consisted of several sessions. Computer-assisted guidance was usually limited to a single session.

9. Assuming that the sample was a representative one, it seems that efficient use of modern information technology by Israeli high school students writing a final research paper is still far off. Most students are aware of the powerful new IT tools, and in principle they overwhelmingly agree with statements such as "searching the Internet and information databases enhances learning pleasure and is not too complicated", or that "the ability to master and navigate the vast ocean of information is a basic condition for success in the 21 st century". In fact, however, their use is not as common as may be assumed, mainly due to poor or inadequate guidance.

10. Further research is recommended in the form of a follow-up study, incorporating qualitative research techniques, to determine if information seeking patterns of local high school students are shifting towards more guidance given and greater use of modern IT and to determine factors conducive to or delaying this change.

\section{REFERENCES}

American Association of School Librarians \& Association for Educational Communications and Technology. (1998). Information Power; Building Partnerships for Learning. Chicago: ALA.

American Association of School Librarians \& Association for Educational Communications and Technology. (1998). Information Literacy Standards for Student Learning. Chicago and London: ALA.

Barlow, D. (1987). CD-ROM in a high school library media center. School Library Journal, $34(3), 66-68,70-72$.

Burdik, T. A. (1996). Success and diversity in information seeking: Gender and the information search styles model. School Library Media Quarterly, 25 (1), 19-26. 
Callison, D. (1997). Evolution of methodes of measure student information use. Library and Information Science Research, 19 (4), 347-357.

Chen, S. H. (1993). A study of high school students' online catalog searching behavior. School Library Media Quarterly, 22 (1), 33-39.

Donitza-schmidt, S., \& Levin, T. (1997). Attitudes and stereotypes regarding computers. Eyunim Betechnologia, 27, 34-37. (in Hebrew).

Drott, M. C., Mancall, J. C. (1980). Magazines as information sources: Patterns of student use. School Media Quarterly, 8 (4), 240-244, 249-250.

Fidel, R. (1999). A visit to the information mall: Web searching behavior of high school students. Journal of the American Society for Information Science, 50 (1), 24-37.

Getz, A. (1985). Patterns of bibliographic search among students doing final papers. Unpublished master's thesis. The Hebrew University School of Librarianship, Jerusalem. (in Hebrew).

Getz, A. (1988). Bibliographic search done by students doing final papers. Yad LaKore, 23, 29-47. (in Hebrew).

Kuhlthau, C. C. (1985). A process approach to library skills instruction. School Library Media Quarterly, 13 (1), 35-40.

Kuhlthau, C. C. (1988). Developing a model of the library search process: Cognitive and affective aspects. $R Q, 28(2), 232-242$.

Latrobe, K., Havener, W. M. (1997). The information-seeking behavior of high school honors students: An exploratory study. Journal of Youth Services in Libraries, 10 (2), 188200.

Liebscher, P., \& Marchionini, G. (1988). Browse and analytical search strategies in a fulltext cd-rom encyclopedia. School Library Media Quarterly, 16 (4), 223-233.

McGregor, J. H. (1994a). Cognitive processes and the use of information: A qualitative study of higher order thinking skills used in a gifted program. School Library Media Annual, 12, 124-133.

McGregor, J. H. (1994b). Information seeking and use: Students' thinking and their mental models. Journal of the Youth Services in Libraries, 8 (1), 69-76.

Nahl, D., \& Harada, V. H. (1996). Composing Boolean search statements: Self-confidence, concept analysis, search logic, and errors. School Library Media Quarterly, 24 (4), 199-207.

Neumam, D. (1995). High school students' use of databases: Results of a national delphi study. Journal of the American Society For Information Science, 46 (4), 284-298.

Pitts, J. M. (1995). The 1993-1994 AASL/Highsmith research award study: mental models of information. School Library Media Annual, 13, 187-200.

Shoham, S., Getz, I. (1988). Patterns of bibliographic searching among Israeli high school students. Library and Information Science Research, 10 (1), 57-75.

Soloway, E., Wallace, R. (1997). Does the Internet support student inquiry? Don't ask. Communication of the ACM, 40 (5), 11-16.

Shtater, S. (1998). Problems, processes and products of final research papers in biology done by high school students in Israel. Unpublished doctoral dissertation. The Hebrew University, Jerusalem. (in Hebrew). 